\title{
Evaluation of Methane Production From Dairy Cow Manure and Vegetable Waste
}

\author{
Ephodia Sihlangu ${ }^{1}$, Dibungi Luseba ${ }^{1}$, Khathutshelo A. Nephawe ${ }^{1}$ \& Florence V. Nherera-Chokuda ${ }^{2}$ \\ ${ }^{1}$ Department of Animal Sciences, Tshwane University of Technology, South Africa \\ ${ }^{2}$ Red Meat Research Policy \& Development Hub Southern Africa, Pretoria, South Africa \\ Correspondence: Ephodia Sihlangu, Department of Animal Sciences, Tshwane University of Technology, \\ Staatsartillerie Rd, Pretoria West, Pretoria, 0183, South Africa. Tel: 27-123-825-118. E-mail: \\ sihlanguephodia@gmail.com
}

Received: December 7, $2020 \quad$ Accepted: February 7, $2021 \quad$ Online Published: March 15, 2021

doi:10.5539/jas.v13n4p27 URL: https://doi.org/10.5539/jas.v13n4p27

The research is financed by National Research Foundation (NRF).

\begin{abstract}
Dairy cow manure has high buffering capacity hence a substrate for anaerobic digestion, however the process is not optimised in mono-digestion system due to limited substrate. The aim of the study was to assess the effect of co-digesting animal waste and vegetable waste on methane production. Two systems were applied- batch and continuous anaerobic digestion system to determine effect on methane yield. The experiments were conducted with treatments as: manure alone (M), composite of manure with cabbage (MC), manure with potatoes (MP), manure with cabbage and potatoes (MCP), faecal alone (F), faecal with cabbage (FC), faecal with potatoes (FP) and faecal with cabbage and potatoes (FCP). Rectal grab samples were collected prior to incubation and manure was collected from the pens. All treatments were in replicates. Composite of manure or faecal with cabbage and potatoes produced the highest biogas (FCP: $32.1 \mathrm{~mL} / \mathrm{g}$ DM, MCP: $29.5 \mathrm{~mL} / \mathrm{g} \mathrm{DM}$ ) and methane (FCP: 3.13 $\mathrm{mL} / \mathrm{g}$ DM, MCP: $2.36 \mathrm{~mL} / \mathrm{g} \mathrm{DM}$ ) compared to manure alone or faecal alone (F: 27.0 biogas $\mathrm{mL} / \mathrm{g} \mathrm{DM}, \mathrm{M}: 26.6$ biogas $\mathrm{mL} / \mathrm{g} \mathrm{DM}$ ) (F: 1.36 methane $\mathrm{mL} / \mathrm{g} \mathrm{DM}, \mathrm{M}: 1.18$ methane $\mathrm{mL} / \mathrm{g} \mathrm{DM})$. Co-digesting dairy excreta with cabbage as only vegetable substrate affected anaerobic digestion (FC: $24.8 \mathrm{~mL} / \mathrm{g} \mathrm{DM}, \mathrm{MC}: 24.9 \mathrm{~mL} / \mathrm{g} \mathrm{DM}$ ), since it was the lowest in biogas production compared to all treatments. The anaerobic digestion system had an effect in methane production since continuous anaerobic digestion system produced the highest methane compared to batch anaerobic digestion system in all treatments. The results obtained in this study suggest that composite of manure with both cabbage and potatoes results in the highest biogas and methane production.
\end{abstract}

Keywords: biogas production, dairy cow manure, methane production, vegetable waste

\section{Introduction}

The Environmental consequences of animal manure disposal have motivated experts to seek for strategies which could lead to sustainable farming. Solutions that could help to transmute manure into value-added marketable products and environmentally friendly. Manure is one of the biodegradable products and should not be disposed in landfills since it contains substantial levels of harzadous pathogens and nutrients (Neshat et al., 2017). Any mismanagement of this valuable waste may lead to contamination of water sources, soil, air pollution, and harmful microbial build-up in the environment. Anaerobic digestion is one of the best waste management practices, whereby biogas and quality fertilisers are produced. Anaerobic digestion is the process by which microbes' breakdown organic material under oxygen free environment to produce mainly methane and carbon dioxide (Sebola, Tesfagioggis, \& Muzenda, 2014).

An increase in human population has led to a mass-production of animals in farms to meet food requirement of the growing population. This in return results in high amount of manure produced by animals (Moeletsi \& Tongwane, 2015). Management of huge amount of waste produced daily is a challenge and an understanding on how to wisely utilise manure on the farm is in demand. The nutrients in the manure makes it a valuable commodity, however the same nutrients in the manure makes it a threat to the environment (Mu et al., 2017). 
Even though anaerobic digestion is the best alternative to manure disposal on open land, conversely, the low carbon to nitrogen ratio cannot successfully meet the requirement of anaerobic digestion (Neshat et al., 2017). Hence there is a need to co-digest manure with another carbon-rich substrate. Anaerobic co-digestion results in high production of biogas than mono-digestion. The characteristics of co-substrates utilised for co-digestion is vital; substrates with high carbon and low nitrogen are preferred. Vegetable waste such as cabbage and potatoes seem promising as they are rich in carbon and abundantly available at low cost throughout the year (Patil \& Deshmukh, 2015). The current study was designed to assess the biogas production from dairy cow manure co-digested with vegetable waste and to assess the effect of batch anaerobic digestion and continuous anaerobic digestion on methane production. Dairy cow manure is one of the good substrates for anaerobic digestion because of its high buffering capacity, which aid in stable anaerobic digestion.

\section{Methods}

\subsection{Study Area}

The study was conducted at Agricultural Research Council (ARC) in Irene at Animal nutrition section, South Africa. The climatic classissification of the area is $\mathrm{Cwb}$, which means subtropical highland climate.The area is situated in the Highveld at an altitude of $1525 \mathrm{~m}$ above sea level. The weather conditions range from hot days and cool nights in summer $\left(17.5{ }^{\circ} \mathrm{C}\right.$ to $\left.32{ }^{\circ} \mathrm{C}\right)$ to moderate winter days with cold nights $\left(1{ }^{\circ} \mathrm{C}\right.$ to $\left.17{ }^{\circ} \mathrm{C}\right)$ (Grobbelaar, Sutherland, \& Molalakgotla, 2010).

\subsection{Ethical Statement}

The study was approved by Tshwane University of Technology ethics committee (Ref No: AREC2015/10/007) and Agricultural Research Council ethics committee (Ref No: APIEC16/027), before the experiments were conducted.

\subsection{Substrates Collection}

Fresh manure $(2 \mathrm{Kg})$ was collected using a clean basket from the floor. Faecal samples $(2 \mathrm{~kg})$ were randomly collected using a clean and sanitized hand gloves. Faecal samples were collected from the dairy cows placed in a comfortable crush pen for easy rectum manure collection and hands were washed between each and every animal and gloves were changed between each animal. Collected samples were dried at $60{ }^{\circ} \mathrm{C}$ using an oven for 48 hours prior to grinding. The sample was grinded to $1 \mathrm{~mm}$ particle size. The sample was stored in an air tight container away from the sun for further analysis. Vegetable wastes (cabbage and potatoes) were collected from Tshwane market and Marabastad and then washed (to remove soil particles). Cabbage and potatoes were dried at $60{ }^{\circ} \mathrm{C}$ for 24 hours in an air tight circulating oven. The sample was then grinded to $1 \mathrm{~mm}$ particle size and stored in an air tight container.

\subsection{Analytical Methods}

All samples collected were dried and analysed in triplicates for DM, ash, EE and CP using laboratory standard procedures (AOAC, 2000). The CP was determined using the Kjeldahl method. The NDF, ADF and ADL were analysed following Van Soest et al. (1991). The $\mathrm{pH}$ was determined using extech $407228 \mathrm{pH} / \mathrm{mV} /$ Temperature Meter Kit (USA). The gas production was determined using ANKOM gas production system (ANKOM ${ }^{\mathbb{B}}$ Technologies corp., Fairport, NY) and methane content was determine using laser methane mini (LMm) ATEX-rated, laser-based remote methane. The biological characteristics of feedstuff used for batch and continuous digestion are shown in Table 1. 
Table 1. Biological characteristics of substrates in Dry-Matter basis

\begin{tabular}{lllll}
\hline Parameters & Potato wastes & Cabbage wastes & Manure & Faecal \\
\hline$\% \mathrm{NDF}$ & 16.34 & 28.20 & 67.18 & 67.58 \\
$\% \mathrm{ADF}$ & 3.76 & 7.88 & 30.25 & 27.25 \\
$\% \mathrm{ADL}$ & 0.71 & 1.37 & 6.53 & 6.49 \\
$\% \mathrm{CP}$ & 11.89 & 9.01 & 8.93 & 8.89 \\
$\% \mathrm{EE}$ & 0.43 & 2.48 & 0.93 & 0.91 \\
$\% \mathrm{DM}$ & 16.85 & 12.21 & 22.04 & 21.68 \\
$\% \mathrm{CA}$ & 1.11 & 6.75 & 9.04 & 8.96 \\
$\% \mathrm{HC}$ & 3.06 & 6.63 & 23.72 & 20.76 \\
$\mathrm{pH}$ & 5.0 & 80.25 & 6.61 & 6.65 \\
$\% \mathrm{ODM}$ & 92.89 & 90.96 & 91.04 \\
\hline
\end{tabular}

Note. \% NDF: percentage Neutral Detergent Fibre, \% ADF: percentage Acid Detergent Fibre, \% ADL: percentage Acid Detergent Lignin, \% CP: percentage Crude Protein, \% EE: percentage Ether Extract, \% DM: percentage Dry Matter, \% CA: percentage Crude Ash, \% HC: percentage Hemicellulose, \% ODM: percentage Organic Dry Matter.

\subsection{In vitro Gas Production Test}

The bottle of $250 \mathrm{ml}$ volume was used. The content was in the ratio of 1:1 (sample: water) and were manually stirred and incubated at $39{ }^{\circ} \mathrm{C}$. The gas reading for each incubation bottle was recorded every hour using an Ankom gas module (Ankom Technology, Macedon, NY, USA).

ANKOM gas production system records gas production in pressure (psi). The continuous readings provided with automatic gas production make it possible to mathematically describe gas production curves (Cornou et al., 2013). The values recorded were converted to moles of gas produced using 'ideal' gas law and converted to millilitres of gas produced using Avogadro's law as stated by the ANKOM system.

The following equation was applied:

$$
\mathrm{n}=\mathrm{p} \cdot \frac{\mathrm{V}}{\mathrm{RT}}
$$

where, $\mathrm{n}=$ gas produced in moles $(\mathrm{mol}) ; \mathrm{p}=$ pressure in kiloPascal $(\mathrm{kPa}) ; \mathrm{V}=$ head space volume in the glass bottle in litres $(\mathrm{L}) ; \mathrm{T}=$ temperature in Kelvin $(\mathrm{K}) ; \mathrm{R}=$ gas constant $\left(8.314472 \mathrm{~L} \mathrm{kPa} \mathrm{K}^{-1} \mathrm{~mol}^{-1}\right)$.

To convert gas volumes in $\mathrm{mL}$ at standard temperature and pressure, the Avogadro's law was applied. The law hypothesise that at atmospheric pressure measured in psi $(1 \mathrm{psi}=6.8947577293$ kiloPascal $), 1$ mole occupies 22.41 at $273.15{ }^{\circ} \mathrm{K}$ and $101.325 \mathrm{kPa}$. The gas measured in moles was converted to gas measured in $\mathrm{mL}$ as follows:

$$
\text { Gas produced in } \mathrm{ml}=\mathrm{n} \times 22.4 \times 1000
$$

\subsection{Methane Anaerobic Digestion Set-Up}

The batch and continuous fermentation system were set up. They were managed under anaerobic mesophilic condition (38-39 $\left.{ }^{\circ} \mathrm{C}\right)$ with treatments: (A) control-manure/faecal, (B) manure/faecal and cabbage, (C) manure/faecal and Irish potatoes and (D) manure/faecal, cabbage and potatoes. In both fermentation systems, water to substrate ratio was $1: 1$ in $250 \mathrm{~mL}$ bottle and fermented for 120 hours. The continuous fermentation system was fed daily with the orgainic loading rate of $1 \mathrm{~g} / \mathrm{DM}$ and the equal amount was discharged daily. The Methane was measured every 24 hours using laser methane mini (LMm) ATEX-rated, laser-based remote methane detector. The experiment was conducted as a Randomised Complete Block Design (RCBD) with different sample collection as a blocking factor. The experimental designs are shown in Table 2. 
Table 2. Experimental design of manure co-digested with vegetable wastes

\begin{tabular}{lll}
\hline Sample & Treatments & Description \\
\hline \multirow{3}{*}{ Manure from the floor } & Manure (control) & $100 \%$ manure \\
& Manure and cabbage & $75 \%$ manure and $25 \%$ cabbage \\
& Manure and potato & $75 \%$ manure and $25 \%$ potato \\
Faecal from the rectum & Manure,cabbage and potato & $75 \%$ manure, $12.5 \%$ potato and $12.5 \%$ cabbage \\
& Faecal (control) & $100 \%$ manure \\
& Faecal and cabbage & $75 \%$ manure and $25 \%$ cabbage \\
& Faecal and potato & $75 \%$ manure and $25 \%$ potato \\
& Faecal, cabbage and potato & $75 \%$ manure, $12.5 \%$ potato and $12.5 \%$ cabbage \\
\hline
\end{tabular}

\subsection{Characteristics Statistical Analysis}

All the data such as potential gas production, rate of gas production, methane production and $\mathrm{pH}$ were subjected to analysis of variance using General Linear Model (GLM) procedures in Minitab Statistical Software, Version 17 (Minitab, 2010). Treatment means were compared using a Fishers' least significant difference (LSD) and significant differences were declared at $\mathrm{p}<0.05$.

\section{Results}

\subsection{Effect of Dairy Manure Co-digested with Vegetable Waste on Biogas Production}

Biogas production and rate of biogas production are shown in Table 3. The highest biogas production was achieved from co-digestion of dairy manure, cabbage and potatoes (FP: $32.6 \mathrm{~mL}, \mathrm{FCP}: 32.1 \mathrm{~mL}$, MCP: $29.5 \mathrm{~mL}$ ). The lowest biogas production was observed from dairy manure co-digested with cabbage alone (MC: $24.9 \mathrm{~mL}$, FC: $24.8 \mathrm{~mL}$ ). The trend observed in all treatments was the same, whereby biogas production increased with time. However the rate of biogas production varied between treatments.

Table 3. Biogas production and rate of biogas production $(\mathrm{mL} / \mathrm{g} \mathrm{DM})$

\begin{tabular}{lll}
\hline \multirow{2}{*}{ Treatment } & \multicolumn{2}{c}{ Parameter } \\
\cline { 2 - 3 } & Potential gas production & Rate of gas production \\
\hline M & $26.6 \pm 0.23^{\mathrm{b}}$ & $0.05 \pm 0.00^{\mathrm{b}}$ \\
MC & $24.9 \pm 0.59^{\mathrm{c}}$ & $0.06 \pm 0.04^{\mathrm{a}}$ \\
MP & $26.3 \pm 0.16^{\mathrm{b}}$ & $0.06 \pm 0.02^{\mathrm{a}}$ \\
MCP & $29.5 \pm 0.73^{\mathrm{a}}$ & $0.05 \pm 0.01^{\mathrm{b}}$ \\
\hline Average & 26.83 & 0.05 \\
\hline F & $27.0 \pm 0.13^{\mathrm{b}}$ & $0.05 \pm 0.00^{\mathrm{c}}$ \\
FC & $24.8 \pm 0.03^{\mathrm{c}}$ & $0.07 \pm 0.00^{\mathrm{a}}$ \\
FP & $32.6 \pm 0.04^{\mathrm{a}}$ & $0.06 \pm 0.00^{\mathrm{b}}$ \\
FCP & $32.1 \pm 0.32^{\mathrm{a}}$ & $0.07 \pm 0.00^{\mathrm{a}}$ \\
\hline Average & 29.13 & 0.06 \\
\hline
\end{tabular}

Note. ${ }^{\text {abc }}$ Means within a column with different superscripts differ $(p<0.05)$.

\subsection{Effect of Dairy Manure Co-digested with Vegetable Waste on Methane Production}

Methane production from manure and faecal (rectal manure) co-digested with vegetable waste are illustrated in Figure 1. An increase in methane production was observed in all treatments co-digested with cabbage and potato waste. Anaerobic co-digestion of both cabbage and potato waste simultaneously attained the highest methane production (FPC: $3.13 \mathrm{~mL}$, MPC: $2.36 \mathrm{~mL}$ ). Co-digestion of dairy manure with either cabbage or potato waste produced more methane in comparison with the mono anaerobic digestion of manure or faecal sample (rectal manure). All treatments were observed to be significantly different $(\mathrm{p}<0.05)$. 


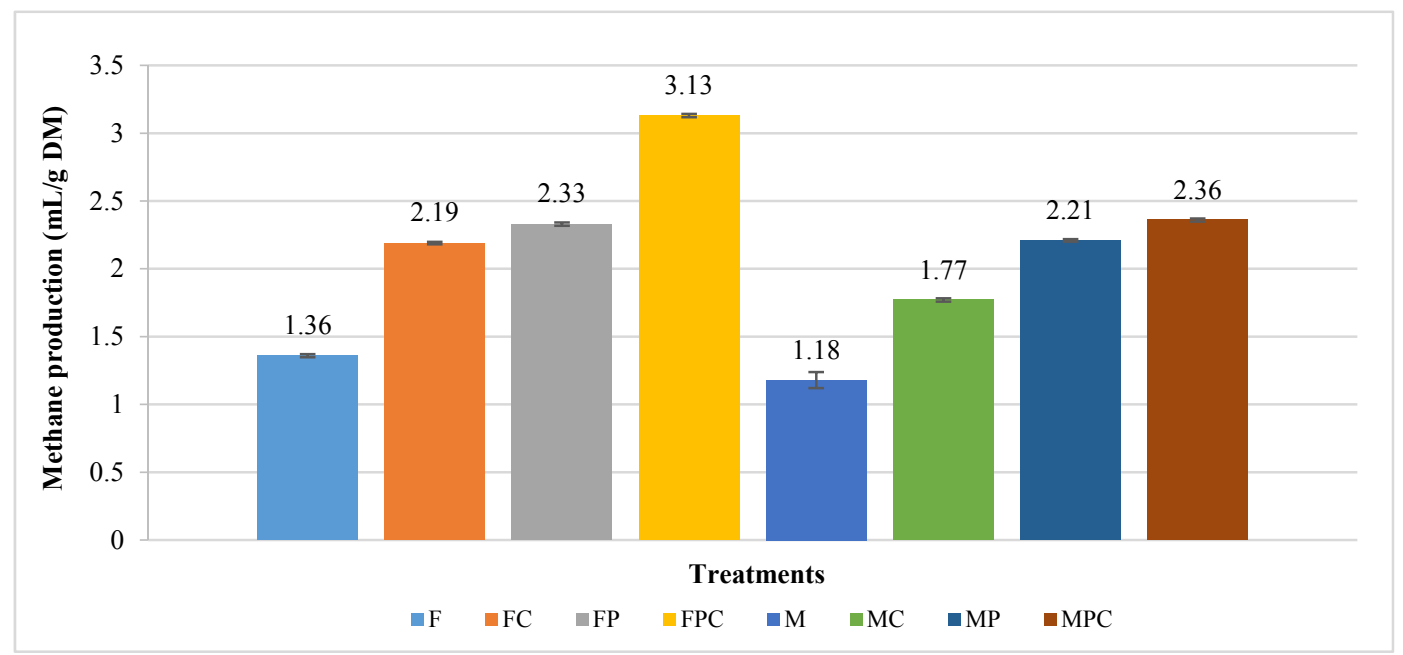

Figure 1. Methane production from manure/faecal co-digested with cabbage and potato waste

\subsection{Batch and Continuous System Performance on Methane Production and $\mathrm{pH}$}

The performance of batch and continuous system on methane yield are shown in Figure 2. The methane production in the continuous system was high in all treatments compared to the batch system. Anaerobic co-digestion of manure with both cabbage and potatoes produced more methane in the batch system and in the continuous system. In continuous system, mono-anaerobic digestion of manure performed better in terms of methane production compered to anaerobic co-digestion of manure and cabbage.

The $\mathrm{pH}$ of the batch and continuous system are illustrated in Table 7. The initial $\mathrm{pH}$ of the batch and continuous system were the same, however the final $\mathrm{pH}$ between batch and continuous system was highly significant $(\mathrm{P}<$ 0.05). In all treatments a low $\mathrm{pH}$ was observed in batch system compared to continuous system.

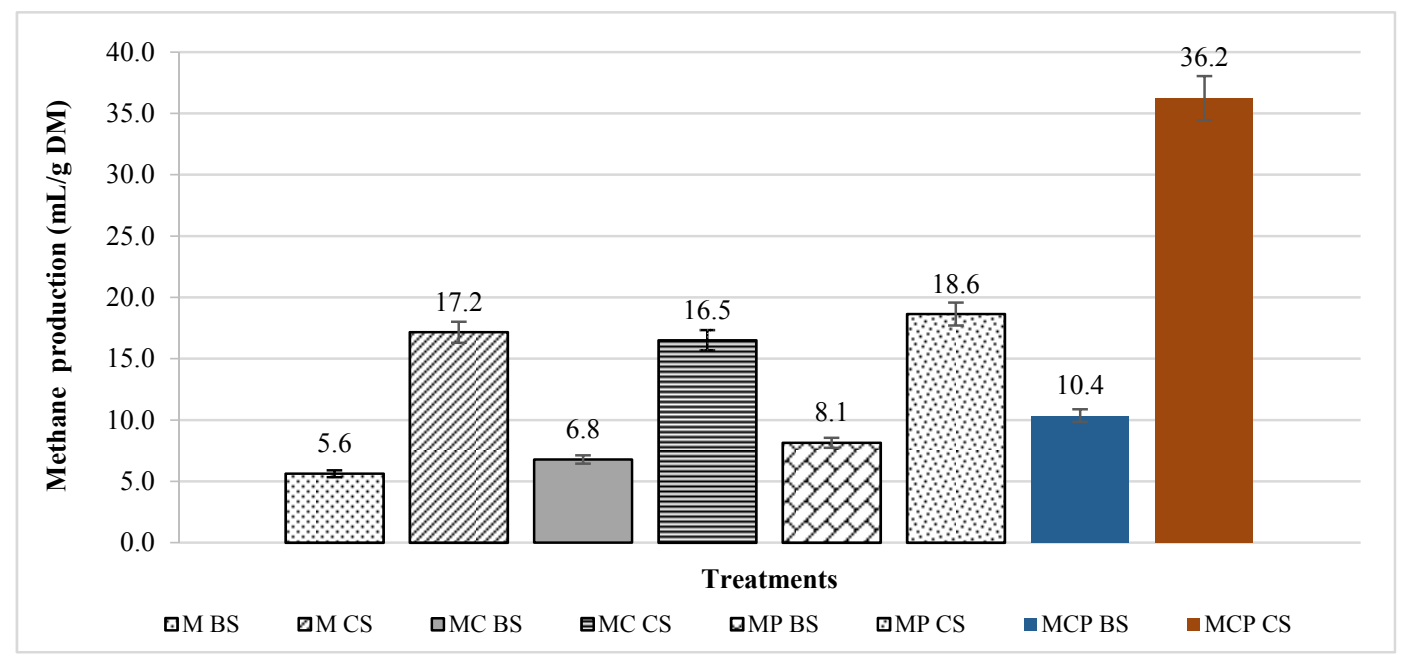

Figure 2. Performance of batch and continuous system on methane yield

Note. M BS: manure Batch system, MC BS: manure and cabbage wastes Batch system, MP BS: manure and potato wastes Batch system, MCP BS: manure, cabbage and potato wastes Batch system, M CS: manure continuous system, MC CS: manure and cabbage wastes continuous system, MP CS: manure and potato wastes continuous system, MCP: manure, cabbage and potato wastes continuous system. 
Table 7. The $\mathrm{pH}$ of batch and continuous system

\begin{tabular}{llll}
\hline \multirow{2}{*}{ Treatments } & Initial & Batch & Continuous \\
\cline { 2 - 4 } & $\mathbf{0 . 0}$ hrs & $\mathbf{1 2 0} \mathbf{~ h r s}$ & $\mathbf{1 2 0}$ hrs \\
\hline M & $6.8 \pm 0.38$ & $6.2^{\mathrm{b}} \pm 0.47$ & $6.4^{\mathrm{a}} \pm 0.49$ \\
MC & $7.5 \pm 0.35$ & $5.4^{\mathrm{b}} \pm 0.27$ & $6.3^{\mathrm{a}} \pm 0.33$ \\
MP & $7.1 \pm 0.20$ & $6.1^{\mathrm{b}} \pm 0.31$ & $6.9^{\mathrm{a}} \pm 0.44$ \\
MCP & $7.4 \pm 0.19$ & $6.3^{\mathrm{b}} \pm 0.63$ & $6.8^{\mathrm{a}} \pm 0.11$ \\
\hline
\end{tabular}

Note. ${ }^{\text {ab }}$ Means across a row with different superscripts differ $(\mathrm{P}<0.05)$.

M: manure; MC: manure and cabbage wastes; MP: manure and potato wastes; MCP: manure, cabbage and potato wastes.

\section{Discussion}

\subsection{Effect of Dairy Manure Co-digested With Vegetable Waste on Biogas Production}

Co-digestion of dairy manure with vegetable waste enhances biogas production. The fermentation of single organic waste is more likely to fail and this may be due to free ammonia inhibition that exist when livestock manure are digested alone (Shah et al., 2015). The process of co-digesting more than one substrates improves nutrient balance, biogas production, control $\mathrm{C} / \mathrm{N}$ ratio and reduces toxic compounds on the digestion process (Ajay et al., 2011). This statement is also supported by the study done by Mu et al. (2017) whereby the mixture of both cabbage and potatoes produced the highest biogas compared to single digestion of each vegetable waste. Co-digesting manure with vegetable wastes was evaluated in this study. It was observed that manure or faecal co-digested with both cabbage and potato wastes resulted in an increase of biogas production, compared to manure alone. Comparable results were obtained from the study done by Kassuwi, Mshandete, and Kivaisi (2012); however, manure was co-digested with cabbage only or potatoes only

The results from faecal (faecal collected from the rectum) and faecal co-digested with vegetable waste performed better in terms of biogas production compared to manure (manure collected from the floor) digested as a single substrate and manure co-digested with vegetable waste. This could have been initiated by microbial activities which were alive and already fermenting in the faeces, unlike in manure which was already exposed to aerobic conditions and uncontrolled temperature. From this study it was observed that biogas production from manure or faecal sample co-digested with cabbage only was low in biogas production compared to manure co-digested with potato waste. These results concurred with findings of Mu et al. (2017). The plausible reason is that potatoes are rich in starch, which is easily digested and contain $84 \%$ water, which enhance moisture content in the digester. Some studies have shown that biogas production and performance of the processes are significantly improved when manure is co-digested with both cabbage and potatoes at the ratio of $1: 1$. This balance the $\mathrm{C} / \mathrm{N}$ ratio (2-30) which is desirable for biogas production (Kim et al., 2006; Liang \& McDonald, 2015).

\subsection{Effect of Dairy Manure Co-digested With Vegetable Waste on Methane Production}

Biogas contains mainly methane that is essential for renewable energy. Various studies reported that co-digestion of manure with other organic substrates increased methane production and this could be attributed to additional nutrients such as carbon, phosphorus and nitrogen (Yadanaparthi \& Chen, 2013; Mamun \& Torii, 2015; Liang, Armando, \& McDonald, 2015). In the current study, it was observed that the highest methane yield was from faecal or manure co-digested with both cabbage and potatoes. Potato waste as a co-substrate yielded higher methane compared to cabbage waste. The results are in agreement to those reported by EI-Mashad and Zhang (2010). Furthermore, similar results were observed from the study done by Yadanaparthi and Chen (2013) on co-digestion of manure with cabbage and potatoes using batch system. The plausible reason could be that the digestion time for cabbage takes longer compared to potatoes, moreover, the cabbage is high in nitrogen, which need more time to undergo hydrolysis and acidogenesis processes (Mu et al., 2017). On the contrary, Dandikas et al. (2014) observed the highest methane production from cabbage waste. The variation in the results reported by other authors and of this study could be due to pre-treatment of substrates before digestion and hydraulic retention time (Mu et al., 2017).

\subsection{Batch and Continuous System Performance on Methane Production and $p H$}

The $\mathrm{pH}$ in a bio-digester is a delicate parameter used to determine bio-digester stability. The optimum $\mathrm{pH}$ reported by several studies ranged between 6.1-8.3 (Yadvika et al., 2004; Kafle et al., 2013). Several studies documented that the $\mathrm{pH}$ below 6.1 and above 8.3 had a low methane production, since methanogens responsible 
for methane yield are active when the $\mathrm{pH}$ is between 6.1- 8.3 (Kafle et al., 2013). In the current study, the $\mathrm{pH}$ in batch system was low compared to continuous system at the end of the digestion. However, all treatments in both systems were still at an optimum $\mathrm{pH}$ range. Sibiya, Muzenda, and Tesfagiorgis (2014) reported that the $\mathrm{pH}$ of the digester is mainly, affected by digester system. The continuous digester system is more stable compared to batch system. These results are in agreement with the results obtained by Deressa et al. (2015).

\section{Conclusion}

Based on the results, vegetable waste such as cabbage and potatoes are good substrates to co-digest simultaneously with dairy manure or faecal to enhance methane production. Cabbage wastes alone as a co-substrate for manure resulted in low $\mathrm{pH}$ and low methane production compared to potatoes waste and this is due to its rapid acidification. The batch digestion system can be used when substrates to be digested are limited. Continuous system was observed to double the amount of methane production compared to batch digester system and it can be used when substrates to be digested are not limited or are readily available.

Significant research efforts are needed regarding inhibitory factors during anaerobic digestion, optimum mixing ratio for different feedstuff and energy potential. Better operation techniques such as two-stage digesters and continuous digesters need to be investigated as well as appropriate organic loading rate and retention time of digestibility. This approach could enhance microbial hydrolysis of substrates and digestibility. In addition, more studies are required to understand types of pre-treatment methods that may be used to enhance digestibility of substrates during digestion.

\section{Acknowledgements}

The authors are grateful to the National Research Foundation (NRF) for funding the study and Agricultural Research Council (ARC) for the permission granted to utilize their laboratories.

\section{References}

Ajay, K. J., Jianzheng, L., Loring, N., \& Liguo, Z., (2011). Research advances in dry anaerobic digestion process of solid organic wastes. African J. Biotechnol., 10, 14242-14253. https://doi.org/10.5897/AJB11.1277

Association of Official Analytical Chemist. (2000). Official methods of analysis (17th ed.). Gaithersburg, Maryland, USA.

Cornou, C., Storm, I. M. L. D., Hindrichsen, I. K., Worgan, H., Bakewell, E., Ruiz, D. R. Y., ... Hansen, H. H. (2013). A ring test of a wireless in vitro gas production system. Animal Production Science, 53, 585-592. https://doi.org/10.1071/AN12091

Dandikas, V., Heuwinkel, H., Lichiti, F., Drewes, J. E., \& Koch, K. (2014). Correlation between biogas yield and chemical composition of energy crops. Biorecource Technology, 174, 316-320. https://oi.org/10.1016/ j.biortech.2014.10.019

Deressa, L., Libsu, S., Chavan, R. B., Manaye, D., \& Dabassa, A. (2015). Production of biogas from fruit and vegetable wastes mixed with different wastes. Environment and Ecology Research, 3(3), 65-71. https://doi.org/10.13189/eer.2015.030303

Ei-Mashad, H. M., \& Zhang, R. (2010). Biogas production from co-digestion of dairy manure and food waste. Bioresource Technology, 101, 4021-4030. https://doi.org/10.1016/j.biortech.2010.01.027

Grobbelaar, J. A. N., Sutherland, B., \& Molalakgotla, N. M. (2010). Egg production potential of certain indigenous chicken breeds from South Africa. Animal Genetics Resources, 46, 25-32. https://doi.org/ $10.1017 / \mathrm{S} 2078633610000664$

Kafle, G. K., Kim, S. H., \& Sung, K. I. (2013). Ensiling of fish industry waste for biogas production: Lab scale evaluation of biochemical methane potential (BMP) and kinetics. Biorecource Technology, 127, 326-336. https://doi.org/10.1016/j.biortech.2012.09.032

Kassuwi, S. A. A., Mshandete, A. M., \& Kivaisi, A. K. (2012). Anaerobic co-digestion of biological pre- treated nile perch fish solid waste with vegetable fraction of market solid waste. Journal of Agricultural and Biological Science, 7(12), 1990-6145.

Kim, S. H., Han, S. K., \& Shin, H. S. (2006). Effect of substrate concentration on hydrogen production and 16S rDNA-based analysis of the microbial community in a continuous fermenter. Process Biochemistry, 41, 199-207. https://doi.org/10.1016/j.procbio.2005.06.013 
Liang, S., Armando, G., \& Mcdonald, E. R. (2015). Lactic acid production from potato peel waste by anaerobic sequencing batch fermentation using undefined mixed culture. Waste Management, 45, 51-56. https://doi.org/10.1016/j.wasman.2015.02.004

Mamun, M. R. A., \& Torii, S. (2015). Possibility of anaerobic co-digestion of cafeteria, vegetable and fruit wastes for biogas production without inoculum source. Renewable Energy and Environmental Engineering, $3(4), 219-225$.

Moeletsi, M. E., \& Tongwane, M. P. (2015). 2004 Methane and Nitrous Oxide Emissions from Manure Management in South Africa. Animals, 5, 193-205. https://doi.org/10.3390/ani5020193

Mu, H., Zhao, C., Zhao, Y., Li, Y, Hua, D., Zhang X., \& Xu, H. (2017). Enhanced methane production by semi-continuous mesophilic co-digestion of potato waste and cabbage waste: Performance and microbial characteristics analysis. Bioresources Technology, 263, 68-97. https://doi.org/10.1016/j.biortech.2017. 03.138

Neshat, S. A., Mohammadi, M., Najafpour, G. D., \& Lahijani, P. (2017). Anaerobic digestion of animal manures and lignicellulosic residues as a potent approach for sustainable biogas production. Renewable and Sustainable Energy Reviews, 79, 308-322. https://doi.org/10.1016/j.rser.2017.05.137

Patil, V. S., \& Deshmukh, H. V. (2015). Anaerobic digestion of Vegetable waste for Biogas generation: A Review International Research Journal of Environment Sciences, 4(6), 80-83.

Sebola, R., Tesfagiogis, H., \& Muzenda, H., (2014). Production of biogas through anaerobic digestion of various waste: Review. International Conference on Chemical Integrated Waste Management and Environmental Engineering, April 15-16, 2014, Johannesburg, SA.

Shah, F. A., Mohamood, Q., Rashid, N., Pervez, A., Raja, I. A., \& Shah, M. M. (2015). Co-digestion pretreatment and digester design for enhanced methanogenesis. Renewable Sustainable Energy Review, 42, 627-642. https://doi.org/10.1016/j.rser.2014.10.053

Van Soest, P. J., Robertson, J. B., \& Lewis, B. A. (1991). Methods for dietary fibre, neutral detergent fibre and non-starch polysaccharides in relation to animal. Nutrition. Journal of Dairy Science, 74, 3583-3597. https://doi.org/10.3168/jds.S0022-0302(91)78551-2

Yadanaparthi, S. K. R., \& Chen, L. (2013). Anaerobic co-digestion of dairy manure with potato waste. American Society of Agricultural and Biological Engineers, Kansas City, Missouri, USA.

Yadvika, S., Sreekrishnan, T. R., Sangeeta, K., \& Vineet, R. (2004). Enhancement of biogas production from solid substrates using different techniques-A review. Bio-resource Technology, 95, 1-10. https://doi.org/ 10.1016/j.biortech.2004.02.010

\section{Copyrights}

Copyright for this article is retained by the author(s), with first publication rights granted to the journal.

This is an open-access article distributed under the terms and conditions of the Creative Commons Attribution license (http://creativecommons.org/licenses/by/4.0/). 